\title{
Foreign Direct Investment in the Visegrad Countries after 2004: Have the Visegrad Countries' Membership in the European Union Changed Something?
}

\author{
Jacek Klich
}

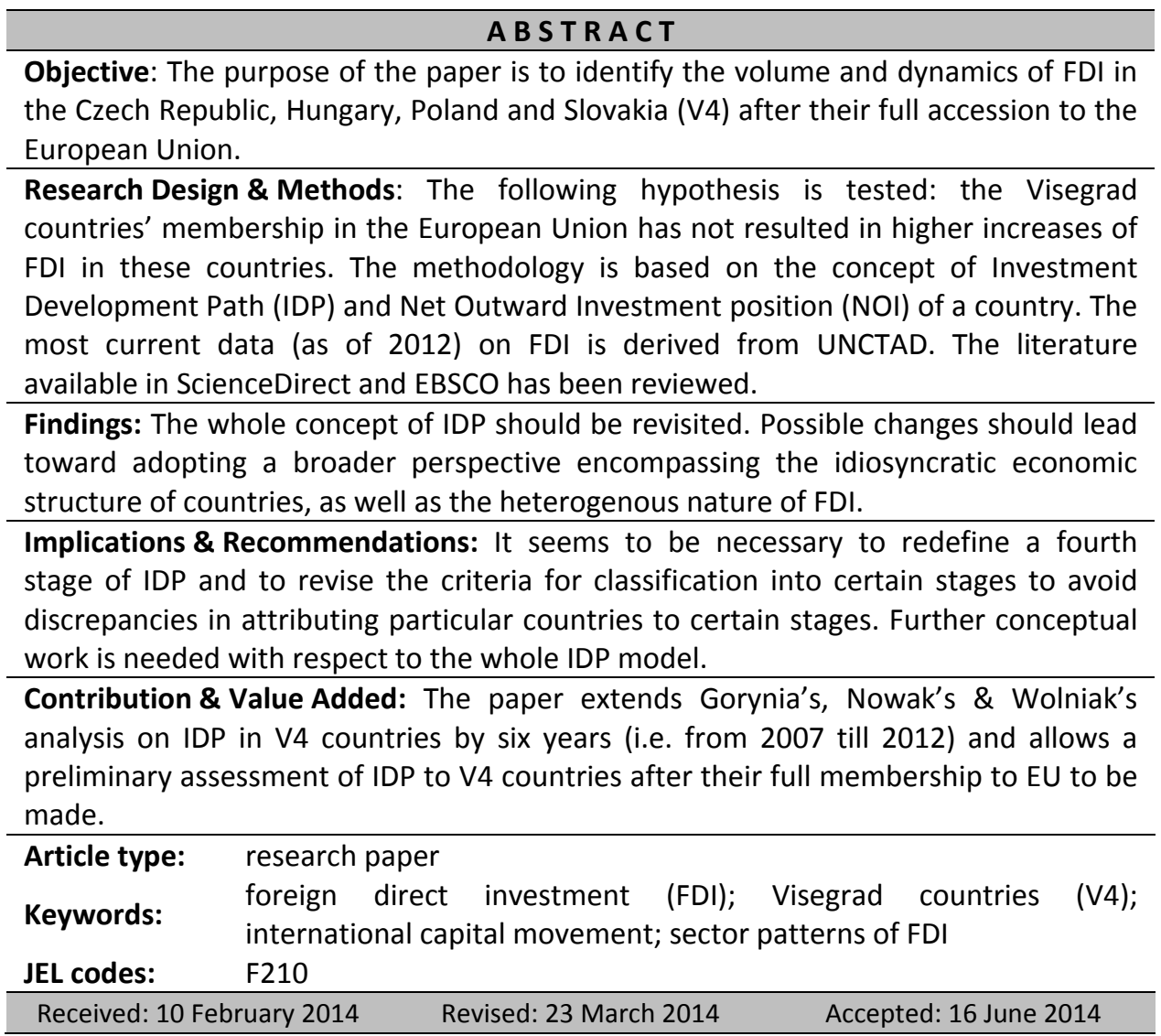

\section{Suggested citation:}

Klich, J. (2014). Foreign Direct Investment in the Visegrad Countries after 2004: Have the Visegrad Countries' Membership in the European Union Changed Something?. Entrepreneurial Business and Economics Review, 2(3), 19-31. 


\section{INTRODUCTION}

In 2012, foreign direct investment (FDI) inflows decreased in all three major economic groups - developed, developing and transitional economies, though at different paces. In developed countries, FDI flows fell by $32 \%$ to 561 billion USD - a level last seen almost ten years ago (UNCTAD, 2013, p. 38). The majority of European Union (EU) countries and the United States experienced significant drops in their FDI inflows.

Outward FDI from developed economies declined by 274 billion USD in 2012, accounting for almost the entire fall in global outward FDI (UNCTAD, 2013, p. 38).

The Czech Republic, Hungary, Poland and Slovakia (hereinafter: Visegrad countries or V4 countries) are classified as developed countries; thus, it could be interesting to inquire how the complicated situation on international markets over the last couple of years influenced FDI dynamics in the V4 countries.

Inspired by Gorynia's, Nowak's \& Wolniak's paper (2010) dealing with - among others - the timeframe and conditions of moving from investment development path (IDP) stage one to stage two, and then issues determining the advance towards IDP stage three ${ }^{1}$ in respect to Central and Eastern European countries, we want to link V4 countries' membership to the European Union with the empirical study by Gorynia, Nowak \& Wolniak ${ }^{2}$ and to ask whether the V4 countries membership in the EU has led towards higher increases in FDI in these countries. Consequently, the hypothesis that the V4 countries' membership in the European Union has not resulted in higher increases in FDI is being tested here, forming the main goal of this paper.

The paper is organized as follows: after the literature review indicating the main streams of analysis of FDI to V4 countries, the method and materials used in the empirical part of the paper are presented. The results and discussion related to the positioning of $\mathrm{V} 4$ countries in the appropriate stages of the Net Outward Investment (NOI) path are then presented, followed by conclusions and few recommendations regarding the further development of the IDP model.

\section{LITERATURE REVIEW}

Considerable flows of FDI to V4 countries started in the early 1990s. The inflow of FDI to V4 countries over the last twenty years has been analyzed from various perspectives showing differences in the dynamics, geography and industry patterns of FDI to the countries at hand (Nowak \& Steagall, 2002).

Due to space limitations, in this short review of the literature ${ }^{3}$ only two issues are raised. The first issue refers to the overall assessment of FDI to V4 countries. There is

\footnotetext{
${ }^{1}$ Stages of IDP are presented in item 3 below.

${ }^{2}$ The empirical study by Gorynia, Nowak \& Wolniak ends at 2006 and thus covers only the first two years of the V4 countries' membership in the EU. The analysis presented in this paper covers eight years of the V4 countries' membership in the EU.

${ }^{3}$ Due to the space limitations, the literature review is scaled (limited) basically to the V4 countries with just a few exceptions and covers mainly papers published after 2004. ScienceDirect (Elseviere) and EBSCO were searched using all of the keywords indicated above, plus "Ivestment Development Path". The search was limited to the period of 2004 until present and to the: abstract, title and keywords field. The selection process
} 
a wide array of literature implying a positive influence of FDI on the V4 countries' economies (Pelinescu \& Radulescu, 2009; Mutascu, Hetes \& Miru, 2010; Nucu, 2005; Zámborský, 2012; Onaran, 2008; Kornecki, 2008; Ambroziak, 2012), to mention just a few.

Along with this, one may find papers presenting less unequivocal findings. Herrmann \& Jochem (2005) found that the net effect of FDI on the trade balance in V4 countries was ambiguous.

Onaran \& Stockhammer (2008) estimated the effect of FDI and trade openness on average sectoral wages in the manufacturing industry in the V4 countries for the period 2000-2004 and utilized a cross-country sector-specific econometric analysis based on one-digit level panel data, and concluded that FDI had a positive effect on wages, but only in the short run (in the medium-run the effect of FDI turned negative). Kravtsova, in her latest empirical analysis (2014), shows that although engagement in exporting and foreign ownership is generally perceived as being beneficial to individual firms and the economy as a whole, in the case of Hungary (which is perceived as a leader in attracting FDI) the effect of such an open policy toward FDI on the Hungarian economy remains unclear. The issue of business friendly policies in theV4 countries was also addressed by Rugraff (2008). Examining the efficiency of the V4 countries' FDI policies by evaluating the spillover effects of foreign investment, he concluded that the "TKC model" (i.e. used in Taiwan, Korea and China), built on strong state intervention in the industrial structure and in the industrial guidance of FDI, has been more efficient in terms of the creation of competitive indigenous firms than the business friendly model implemented in the V4 countries. Kravtsova's and Rugraff's findings correspond with those of Sass (2004).

In this context, one may mention Kuti's (2005) conclusions, according to which FDI has played a substantial, though contradictory role in the modernisation of Hungary.

The second issue refers directly to IDP as a core element of this paper. Although papers and other publications on IDP are present in the literature, there are fewer sources on IDP in the V4 countries. This group consists of works by (Boudier-Bensebaa 2008; Kayam \& Hisarciklilar, 2009; Durán \& Úbeda, 2001; Durán \& Úbeda, 2005; Narula \& Guimón, 2010; Fonseca, Mendonça \& Passos, 2007; Gorynia, Nowak \& Wolniak ,2010; Gorynia, Nowak \& Wolniak, 2007, and - most recently - Stoian, 2013).

Boudier-Bensebaa (2008) undertakes a comparative analysis of IDP in the whole region of Central and Eastern Europe (including V4 countries) and the European Union of the 15 old member states. She concludes that the net outward investment position (NOI) of the V4 countries places them in stages one or two of the IDP, while that of the EU countries points to stages four or five. She draws attention to the fact that data on FDI stocks and GDP does not cover all the factors affecting FDI and development. In the FDI sphere, non-equity forms of investment are omitted. As for the effect on FDI, besides GDP, elements such as EU accession, globalisation and the transformation process

consisted of three stages. In the first stage, all of the 127 articles (altogether) indicated by ScienceDirect and EBSCO were looked through and those not fitting with the research topic were rejected. In the next step, each summary of all the remaining articles (98) was read. Then, based on the summary content, 72 papers were identified for in extenso reading. In the References section, only the most relevant sources are indicated. 
should also be taken into account. This EU accession issue from Boudier-Bensebaa's recommendations has led us to pose the question indicated in the subtitle of this paper.

Gorynia, Nowak \& Wolniak (2010) elaborated on the IDP trajectories of six Central and Eastern European countries: Bulgaria, the Czech Republic, Hungary, Poland, Romania and Slovakia. Earlier, they did similar analysis for Poland (Gorynia, Nowak \& Wolniak, 2007). They classified the V4 countries as belonging to stage two and indicated a paradox in respect to Poland, which being the least developed among V4 countries, appeared to be closest to the point of evolution into the more advanced stage three of the IDP (Gorynia, Nowak \& Wolniak, 2007, p. 14).

Stoian (2013), analyzing outward FDI from 20 Central and Eastern European countries (including V4 countries), comes to the conclusion that IDP's main propositions remain valid and can explain the drivers of FDI outflows: they are positively associated with both GDP per capita and inward FDI. She also highlights the importance of accounting for home country institutional factors when investigating the determinants of outward FDI. Although Stoian claims that IDP still possesses its explanatory power, a vast majority of authors try to improve it (including Dunning who introduced IDP as a research tool in the early 1980s and is cited by all the above-mentioned authors). An example of such an interesting attempt is Kayam's \& Hisarciklilar's (2009) proposition to use fluctuation function obtained from the general solution of an exponential function reflecting a continuous compounding process. It has extra properties that help capture the idiosyncratic shape of IDP and gives parameter estimates that facilitate the interpretation of the stage a country is at. This, in turn, seems to be a key solution to be acknowledged in the literature's ongoing problem with the adequate (i.e. precise enough) classification of a given country to a given IDP stage.

\section{MATERIAL AND METHODS}

\section{Theoretical Framework}

This paper is planned as an extension and further elaboration on Gorynia's, Nowak's \& Wolniak's paper (2010) on the investment development path (IDP) trajectories of V4 countries. Consequently, Investment Development Path (IDP) theory ${ }^{4}$ was used as a theoretical foundation.

IDP theory can be interpreted as an extended form (Kayam \& Hisarciklilar, 2009) of the conditions for the internationalization of firms at the macro level to explain the dynamic relationship between foreign direct investment (FDI) and the level of development of a given country (Dunning cited in Narula \& Guimón, 2010). The IDP model analyzes how patterns in FDI respond to changes in the ownership (O), location (L) and internalization (I) - advantages of firms and countries.

The ownership advantage $(0)$ of a firm depends on its relative competitive advantage, such as patents and licenses, and on its access to raw materials and/or

\footnotetext{
${ }^{4}$ The term "theory" is of a purely conventional nature in this paper. Although it is used in the literature (Fonseca, Mendonça \& Passos, 2007) it is very often referred to as a "concept" (Gorynia, Nowak \& Wolniak, 2007), “model/paradigm" (Gorynia, Nowak \& Wolniak, 2010); “framework" (Narula \& Guimón, 2010), "approach" (Kayam \& Hisarciklilar 2009) or "paradigm" ( Boudier-Bensebaa, 2008).
} 
markets. Location advantages (L) belong to the host country and are defined as factors increasing its attractiveness for FDI such as geographical proximity, labour market specifications (for example skill base, wages) and infrastructure. The internationalization advantage (I) indicates the advantage that the firms plan to exploit themselves rather than sharing or selling to other firms through arms-length contracts (like, for example, franchising) (Kayam \& Hisarciklilar, 2009, pp.63-64). The IDP consists of five stages ${ }^{5}$ which may be observed in most countries (Figure 1).

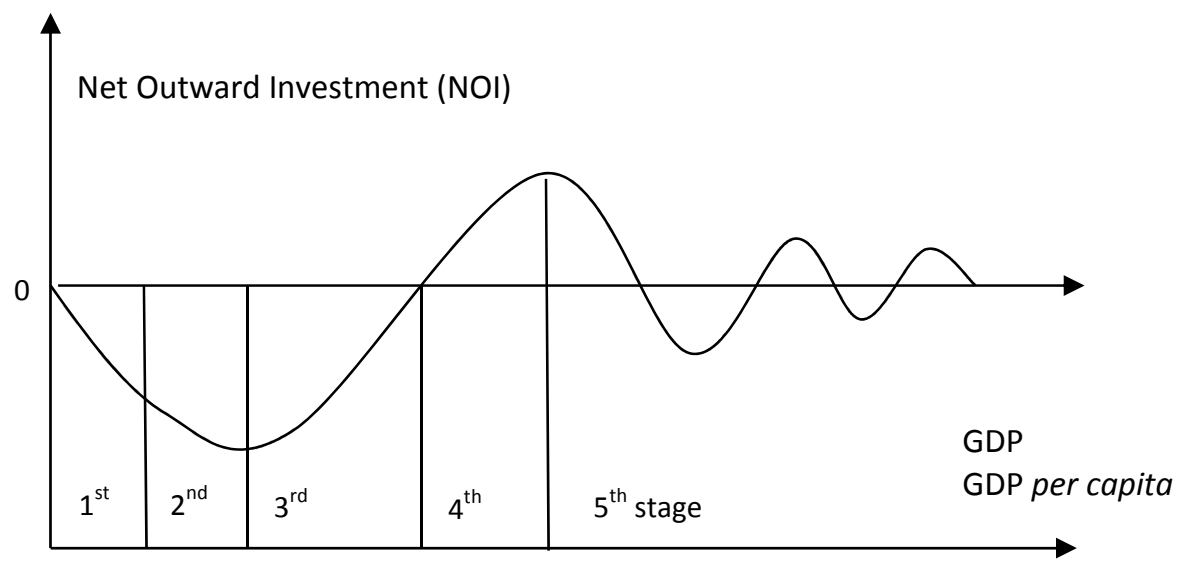

Figure 1. The pattern of the Investment Development Path (IDP)

Source: adapted from Dunning \& Narula (1996) cited in: Fonseca, Mendonça \& Passos (2007, p. 4).

Along these stages, the $\mathrm{O}, \mathrm{I}$, and $\mathrm{L}$ advantages of a country's firms - compared to those of other economies - change, making a country evolve from the position of inward direct investor to outward direct investor.

IDP theory states that a country's net outward investment (NOI) position (measured by the difference of outward and inward foreign direct investment stocks) changes as it develops, where the level of development is measured by gross domestic product (GDP) and GDP per capita. ${ }^{6}$ The relationship between NOI and development is illustrated in Figure 1.

At stage one, the $L$ advantages of the host country are assumed to be insufficient to attract FDI, and, therefore, FDI inflows are a result of natural assets. As would be expected, local (domestic) firms have not developed $\mathrm{O}$ advantages to be in a position to invest abroad, which results in minimal (if any) outflows. At that stage NOI is small and negative.

At stage two, outward investment remains small (or negligible), but the inflows increase as the size and purchasing power of local markets grow. Local (domestic) firms have certain $\mathrm{O}$ advantages, but these are still insufficient to generate more FDI outflows than inflows, which results in decreasing NOI but at a slower rate than in stage one.

\footnotetext{
${ }^{5}$ The first version of the direct IDP proposed four phases. The fifth one was introduced in 1993 (Durán \& Úbeda, 2005, p. 124).

${ }^{6}$ Some authors use gross national product (GNP), see Narula \& Guimón (2010).
} 
Stage three is characterized by a decrease in the growth rate of FDI inward stock accompanied by an increase of outward stock which leads toward a growing NOI position. At the end of stage three, inward and outward FDI stocks are equal.

Stage four means that outward FDI stock is greater than inward FDI stock and the gap between them is growing. At that stage NOI is positive and growing. Stage four terminates when $\mathrm{NOI}$ reaches the maximum (in relative terms) level.

The last stage, stage five, begins when NOI starts to decrease.

Data

Data from UNCTAD statistics was used and organized in a way corresponding to that in Gorynia's, Nowak's \& Wolniak's paper (2010). Since the authors ended their analysis on 2006, in this paper data up to 2012 was collected and the adequate indices were calculated. All the data (excluding population data) is shown in Tables 1 to 6 .

Table 1. NOI and GDP of the Czech Republic in the years 1993-2012

\begin{tabular}{|c|c|c|c|c|c|c|c|}
\hline Year & $\begin{array}{c}\text { NOI } \\
\text { USD } \\
\text { million }\end{array}$ & $\begin{array}{l}\text { GDP* } \\
\text { USD } \\
\text { million }\end{array}$ & NOI/GDP & $\begin{array}{l}\text { NOI per } \\
\text { capita } \\
\text { USD }\end{array}$ & $\begin{array}{l}\text { GDP per } \\
\text { capita } \\
\text { USD }\end{array}$ & $\begin{array}{c}\text { NOl per capita } \\
\text { (previous } \\
\text { year=100) }\end{array}$ & $\begin{array}{c}\text { GDP per capita } \\
\text { (previous } \\
\text { year }=100 \text { ) }\end{array}$ \\
\hline 1993 & -3242 & 39264 & -0.082 & -313 & 3797 & 100.00 & 100.00 \\
\hline 1994 & -4247 & 45631 & -0.093 & -411 & 4411 & 131.31 & 116.17 \\
\hline 1995 & -7005 & 57786 & -0.121 & -677 & 5589 & 164.72 & 126.71 \\
\hline 1996 & -8074 & 64895 & -0.124 & -782 & 6283 & 115.51 & 112.42 \\
\hline 1997 & -8686 & 59464 & -0.146 & -842 & 5767 & 107.67 & 91.78 \\
\hline 1998 & -13571 & 63863 & -0.212 & -1319 & 6206 & 156.65 & 107.61 \\
\hline 1999 & -16854 & 62166 & -0.271 & -1641 & 6053 & 124.41 & 97.53 \\
\hline 2000 & -20906 & 58803 & -0.355 & -2040 & 5737 & 124.31 & 94.78 \\
\hline 2001 & -25956 & 64376 & -0.403 & -2537 & 6292 & 124.36 & 109.67 \\
\hline 2002 & -37196 & 78425 & -0.474 & -3642 & 7678 & 143.56 & 122.03 \\
\hline 2003 & -43003 & 95293 & -0.451 & -4214 & 9339 & 115.71 & 121.63 \\
\hline 2004 & -53499 & 113977 & -0.469 & -5241 & 11165 & 124.37 & 119.56 \\
\hline 2005 & -57052 & 130066 & -0.438 & -5576 & 12713 & 106.39 & 113.86 \\
\hline 2006 & -74824 & 148374 & -0.504 & -7282 & 14440 & 130.60 & 113.58 \\
\hline 2007 & -103851 & 180479 & -0.575 & -10046 & 17458 & 137.96 & 120.90 \\
\hline 2008 & -100643 & 225427 & -0.446 & -9666 & 21651 & 96.22 & 120.02 \\
\hline 2009 & -111022 & 197187 & -0.563 & -10588 & 18805 & 109.54 & 86.86 \\
\hline 2010 & -113581 & 198947 & -0.570 & -10762 & 18850 & 101.64 & 100.24 \\
\hline 2011 & -107355 & 217077 & -0.494 & -10117 & 20458 & 94.00 & 108.53 \\
\hline 2012 & -121266 & $195971^{* *}$ & -0.618 & -11376 & 18384 & 112.44 & 89.86 \\
\hline
\end{tabular}

*current prices and current exchange rates; ${ }^{* *}$ estimation

Source: own calculations based on Gorynia, Nowak \& Wolniak (2010). Data from UNCTADstat.

\section{Periodisation}

In order to verify the hypothesis from the pre-EU accession period, the last eight year period (1996-2004) was defined. The rationale behind this is twofold. Since the analyzed period of V4 countries as full members of the EU is eight years (2004-2012), it is reasonable to compare this eight year period to the last eight year period before the V4 countries' accession to the EU. Additionally, since FDI dynamics were highest during the 
Table 2. NOI and GDP of Hungary in the years 1990-2012

\begin{tabular}{|l|r|r|r|r|r|r|r|}
\hline Year & $\begin{array}{c}\text { NOI } \\
\text { USD } \\
\text { million }\end{array}$ & $\begin{array}{c}\text { GDP* } \\
\text { USD } \\
\text { million }\end{array}$ & NOI/GDP & $\begin{array}{c}\text { NOI per } \\
\text { capita } \\
\text { USD }\end{array}$ & $\begin{array}{c}\text { GDP per } \\
\text { capita } \\
\text { USD }\end{array}$ & $\begin{array}{c}\text { NOI per capita } \\
\text { (previous } \\
\text { year=100) }\end{array}$ & $\begin{array}{c}\text { GDP per capita } \\
\text { (previous } \\
\text { year=100) }\end{array}$ \\
\hline 1990 & -411 & 36.500 & -0.011 & -40 & 3.515 & 100.00 & 100.00 \\
\hline 1991 & -1.948 & 34.106 & -0.057 & -188 & 3.289 & 470.00 & 93.57 \\
\hline 1992 & -3.265 & 38.010 & -0.085 & -315 & 3.667 & 167.55 & 111.49 \\
\hline 1993 & -5.406 & 39.378 & -0137 & -522 & 3.799 & 165.71 & 103.60 \\
\hline 1994 & -6.868 & 42.374 & -0.162 & -663 & 4.090 & 127.01 & 107.66 \\
\hline 1995 & -11.026 & 45.574 & -0.241 & -1.065 & 4.402 & 160.63 & 107.63 \\
\hline 1996 & -13.017 & 45.931 & -0.283 & -1.260 & 4.444 & 118.31 & 100.95 \\
\hline 1997 & -17.321 & 46.533 & -0.372 & -1.680 & 4.513 & 133.33 & 101.55 \\
\hline 1998 & -19.949 & 47.952 & -0.416 & -1.940 & 4.663 & 115.48 & 103.32 \\
\hline 1999 & -22.336 & 48.255 & -0.462 & -2.178 & 4.706 & 112.27 & 100.92 \\
\hline 2000 & -21.590 & 46.386 & -0.465 & -2.112 & 4.537 & 96.97 & 96.41 \\
\hline 2001 & -25.851 & 52.721 & -0.490 & -2.535 & 5.171 & 120.03 & 113.97 \\
\hline 2002 & -34.124 & 66.383 & -0.514 & -3.357 & 6.528 & 132.43 & 126.25 \\
\hline 2003 & -44.831 & 83.538 & -0.536 & -4.420 & 8.237 & 131.67 & 126.18 \\
\hline 2004 & -55.549 & 101.926 & -0.544 & -5.490 & 10.074 & 124.21 & 122.30 \\
\hline 2005 & -53.300 & 110.322 & -0.483 & -5.279 & 10.927 & 96.16 & 108.47 \\
\hline 2006 & -67.785 & 112.533 & -0.602 & -6.727 & 11.167 & 127.43 & 102.20 \\
\hline 2007 & -78.148 & 136.102 & -0.574 & -7.767 & 13.528 & 115.46 & 121.14 \\
\hline 2008 & -70.411 & 154.234 & -0.456 & -7.009 & 15.353 & 90.24 & 113.49 \\
\hline 2009 & -79.067 & 126.663 & -0.624 & -7.882 & 12.627 & 112.46 & 82.24 \\
\hline 2010 & -70.152 & 127.967 & -0.548 & -7.005 & 12.778 & 88.87 & 101.20 \\
\hline 2011 & -60.419 & 138.714 & -0.435 & -6.044 & 13.877 & 86.28 & 108.60 \\
\hline 2012 & -68.816 & $126.785 * *$ & -0.542 & -6.898 & 12.709 & 114.13 & 91.58 \\
\hline
\end{tabular}

*current prices and current exchange rates; **estimation

Source: own calculations based on Gorynia, Nowak \& Wolniak (2010). Data from UNCTADstat.

first years of the post-communist transformation processes (due to the low base in 1990 and in 1993 in respect to the Czech Republic and Slovak Republic), such a time period was set to make the comparison between the increase of inward and outward FDI, as well as NOI, before the V4 countries' accession to the EU more justifiable.

The year 2004 is counted for both time-periods, since the V4 countries' full membership in the EU began on May 1, 2004.

\section{RESULTS AND DISCUSSION}

As indicated in Tables 1-4, all four countries noticed an increase of NOI between 2004 and 2012. The biggest increase (measured by the volume of NOI in USD in 2012 divided by its volume in 2004) was in the Czech Republic, followed by Poland, then Slovakia, and Hungary $(2.27 ; 2.07 ; 1.98$ and 1.23 respectively). The increase of NOI per capita in the period 2004 -2012 (measured by the volume of NOI per capita in USD in 2012 divided by its volume in 2004) mirrored the increase of NOI in USD and was the highest in the Czech Republic and then in Poland, Slovakia and Hungary $(2.17 ; 2.08 ; 1.87$ and 1.26 respectively). 
Table 3. NOI and GDP of Poland in the years 1990-2012

\begin{tabular}{|l|r|r|r|r|r|r|r|}
\hline Year & $\begin{array}{c}\text { NOI } \\
\text { USD } \\
\text { million }\end{array}$ & $\begin{array}{c}\text { GDP* } \\
\text { USD } \\
\text { million }\end{array}$ & NOI/GDP & $\begin{array}{c}\text { NOI per } \\
\text { capita } \\
\text { USD }\end{array}$ & $\begin{array}{c}\text { GDP per } \\
\text { capita } \\
\text { USD }\end{array}$ & $\begin{array}{c}\text { NOI per capita } \\
\text { (previous } \\
\text { year=100) }\end{array}$ & $\begin{array}{c}\text { GDP per capita } \\
\text { (previous } \\
\text { year=100) }\end{array}$ \\
\hline 1990 & -14 & 64.550 & -0.0002 & -0.3 & 1.692 & 100.00 & 100.00 \\
\hline 1991 & -337 & 83.705 & -0.004 & -9 & 2.188 & 3000.00 & 129.31 \\
\hline 1992 & -1.269 & 92.326 & -0.013 & -33 & 2.408 & 366.66 & 110.05 \\
\hline 1993 & -2.109 & 94.122 & -0.022 & -55 & 2.450 & 166.66 & 101.74 \\
\hline 1994 & -3.328 & 108.425 & -0.030 & -87 & 2.819 & 158.18 & 115.06 \\
\hline 1995 & -7.304 & 139.062 & -0.052 & -190 & 3.614 & 218.39 & 128.20 \\
\hline 1996 & -10.728 & 156.684 & -0.068 & -279 & 4.072 & 146.84 & 112.67 \\
\hline 1997 & -13.909 & 157.154 & -0.088 & -338 & 4.086 & 121.15 & 100.34 \\
\hline 1998 & -21.296 & 172.902 & -0.123 & -554 & 4.499 & 163.91 & 110.11 \\
\hline 1999 & -25.051 & 167.802 & -0.149 & -653 & 4.371 & 117.87 & 97.15 \\
\hline 2000 & -33.209 & 171.276 & -0.193 & -866 & 4.466 & 132.62 & 102.17 \\
\hline 2001 & -40.090 & 190.421 & -0.210 & -1.046 & 4.970 & 120.79 & 111.29 \\
\hline 2002 & -46.864 & 198.179 & -0.236 & -1.224 & 5.177 & 117.02 & 104.16 \\
\hline 2003 & -55.728 & 216.801 & -0.257 & -1.457 & 5.668 & 119.04 & 109.48 \\
\hline 2004 & -83.404 & 252.769 & -0.329 & -2.182 & 6.613 & 149.76 & 116.67 \\
\hline 2005 & -84.569 & 303.912 & -0.278 & -2.214 & 7.955 & 101.47 & 120.29 \\
\hline 2006 & -111.390 & 341.597 & -0.326 & -2.916 & 8.944 & 131.71 & 112.43 \\
\hline 2007 & -157.091 & 425.129 & -0.369 & -4.114 & 11.132 & 141.08 & 124.46 \\
\hline 2008 & -140.213 & 529.423 & -0.264 & -3.671 & 13.863 & 89.23 & 124.53 \\
\hline 2009 & -155.895 & 430.912 & -0.361 & -4.082 & 11.282 & 111.20 & 81.38 \\
\hline 2010 & -171.195 & 469.799 & -0.364 & -4.482 & 12.299 & 109.80 & 109.01 \\
\hline 2011 & -148.539 & 514.115 & -0.288 & -3.888 & 13.457 & 86.75 & 109.42 \\
\hline 2012 & -173.079 & $487.528 * *$ & -0.355 & -4.530 & 12.759 & 116.51 & 94.81 \\
\hline
\end{tabular}

${ }^{*}$ current prices and current exchange rates; ${ }^{* *}$ estimation

Source: own calculations based on Gorynia, Nowak \& Wolniak (2010). Data from UNCTADstat.

When comparing the increases of NOI after the V4 countries became EU member states to the period 1996-2004, one may conclude that they were smaller. The highest increase of NOI (measured as stated above) between 1996 and 2004 was recorded in Slovakia, followed by Poland, the Czech Republic and Hungary (respectively: 14.55; 7.77; 6.63 and 4.27). As can be expected, the increase of NOI per capita was the highest in Slovakia, followed by Poland, the Czech Republic and Hungary (14.50; 7.82; 6.70 and 4.36 respectively).

The comparison of $\mathrm{NOI}$ increases during the eight years before and after EU accession shows that the increase between 1996 and 2004 was considerably higher. This, consequently, may support the argument that eight years of membership in the European Union did not result in higher increases in FDI in the V4 countries. This goes for both inward and outward FDIs (see Tables 5 and 6).

Between 1996-2004, the increase of inward FDIs (measured in USD million) was the highest in Slovakia, followed by Poland, the Czech Republic and Hungary (respectively: 13.78; 7.57; 6.80 and 4.64). Between 2004-2012, the biggest increase of inward FDI was in Poland, followed by the Czech Republic, Hungary and Slovakia (respectively: 2.66; 2.38; 2.12 and 1.98). Although one may observe diminishing increases in FDI over the whole analyzed period 1990-2012, the increase during the period 1996-2004 was considerably higher than in 2004-2012. 
Table 4. NOI and GDP of Slovakia in the years 1993-2012

\begin{tabular}{|l|r|r|r|r|r|r|r|}
\hline Year & $\begin{array}{c}\text { NOI } \\
\text { USD } \\
\text { million }\end{array}$ & $\begin{array}{c}\text { GDP* } \\
\text { USD } \\
\text { million }\end{array}$ & NOI/GDP & $\begin{array}{c}\text { NOI per } \\
\text { capita } \\
\text { USD }\end{array}$ & $\begin{array}{c}\text { GDP per } \\
\text { capita } \\
\text { USD }\end{array}$ & $\begin{array}{c}\text { NOI per capita } \\
\text { (previous } \\
\text { year=100) }\end{array}$ & $\begin{array}{c}\text { GDP per capita } \\
\text { (previous } \\
\text { year=100) }\end{array}$ \\
\hline 1993 & -493 & 13.497 & -0.036 & -92 & 2.530 & 100.00 & 100.00 \\
\hline 1994 & -731 & 15.615 & -0.046 & -137 & 2.918 & 148.91 & 115.34 \\
\hline 1995 & -1.158 & 19.587 & -0.059 & -216 & 3.652 & 157.66 & 125.15 \\
\hline 1996 & -1.863 & 21.157 & -0.088 & -347 & 3.938 & 160.65 & 107.83 \\
\hline 1997 & -1.847 & 21.389 & -0.086 & -343 & 3.976 & 98.85 & 100.96 \\
\hline 1998 & -2.512 & 22.378 & -0.112 & -467 & 4.156 & 136.15 & 104.53 \\
\hline 1999 & -2.882 & 20.473 & -0.140 & -535 & 3.801 & 114.56 & 91.46 \\
\hline 2000 & -6.415 & 20.403 & -0.314 & -1191 & 3.787 & 222.62 & 99.63 \\
\hline 2001 & -7.407 & 21.109 & -0.350 & -1375 & 3.918 & 115.45 & 103.46 \\
\hline 2002 & -11.679 & 24.463 & -0.478 & -2168 & 4.540 & 157.67 & 115.88 \\
\hline 2003 & -20.629 & 33.271 & -0.620 & -3829 & 6.176 & 176.61 & 136.04 \\
\hline 2004 & -27.101 & 42.178 & -0.642 & -5030 & 7.828 & 131.37 & 126.75 \\
\hline 2005 & -28.848 & 47.896 & -0.602 & -5351 & 8.884 & 106.38 & 113.49 \\
\hline 2006 & -37.047 & 55.796 & -0.663 & -6864 & 10.338 & 128.28 & 116.37 \\
\hline 2007 & -45.632 & 74.966 & -0.608 & -8441 & 13.867 & 122.97 & 134.14 \\
\hline 2008 & -47.476 & 94.268 & -0.503 & -8767 & 17.409 & 103.86 & 125.54 \\
\hline 2009 & -49.385 & 87.234 & -0.566 & -9103 & 16.080 & 103.83 & 92.37 \\
\hline 2010 & -46.950 & 87.072 & -0.539 & -8642 & 16.027 & 94.94 & 99.67 \\
\hline 2011 & -47.083 & 96.000 & -0.490 & -8655 & 17.647 & 100.15 & 110.11 \\
\hline 2012 & -51.403 & $91.729 * *$ & -0.560 & -9439 & 16.843 & 109.06 & 95.44 \\
\hline
\end{tabular}

*current prices and current exchange rates; **estimation

Source: own calculations based on Gorynia, Nowak \& Wolniak (2010). Data from UNCTADstat.

As far as outward FDI is concerned, between 1996-2004 the highest increase was noticed in Hungary, followed by the Czech Republic, Slovakia and Poland $(22.71 ; 7.5 ; 5.92$ and 4.56 respectively). In the period between 2004-2012, the outward FDI increase was the highest in Poland, then in Hungary followed by Slovakia and the Czech Republic (17.17; $5.77 ; 4.07$ and 4.03 respectively). It is worth noting the high volatility in the increase of outward FDI in Hungary and in Poland, which gives an interesting point of departure for discussion about the stages of the Investment Development Path V4 countries are currently on.

While V4 countries' membership in the EU did not result in a higher increase in FDI to these countries (both inward and outward), it should be indicated that a higher increase in GDP ( measured in USD million, current prices, current exchange rates) was observed in Slovakia and in Poland (respectively: 2.17 against 1.99 and 1.92 against 1.61). The same goes for an increase in GDP per capita: 2.15 against 1.98 for Slovakia and 1.93 against 1.62 for Poland.

In the Czech Republic and Hungary, increases in GDP after 2004 were slightly lower. In respect to the Czech Republic, it was 1.76 versus 1.72 , but in Hungary it was considerably lower (2.22 versus 1.24). These tendencies in GDP were also mirrored in respect to GDP per capita. 


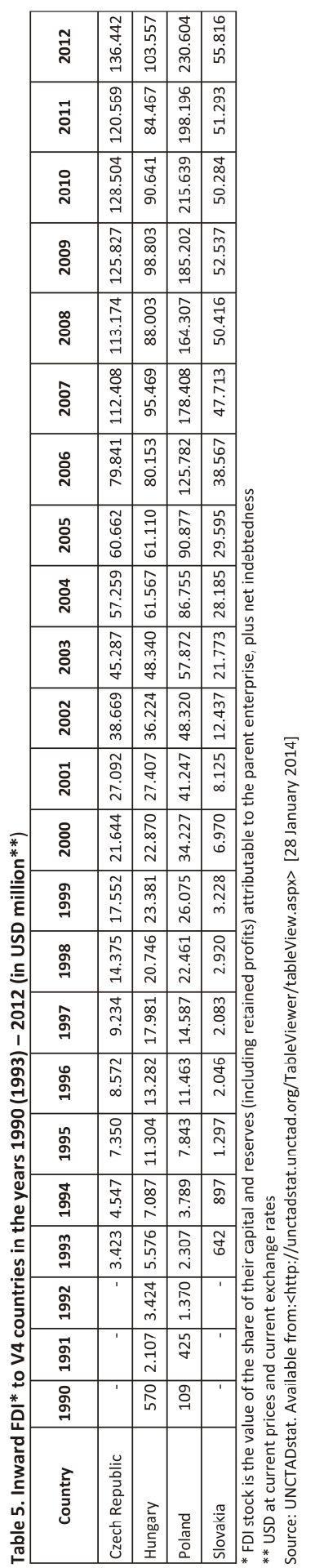

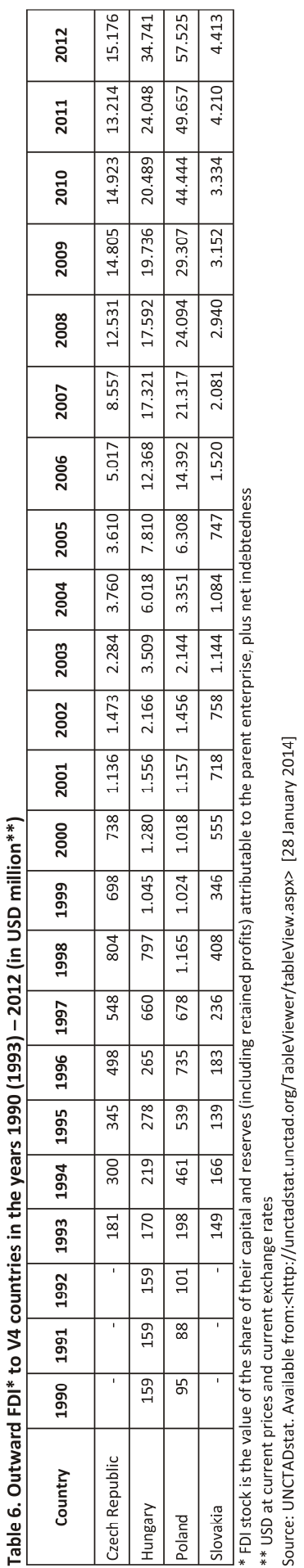


To summarize based upon the above, one may conclude that the hypothesis has been positively verified.

\section{CONCLUSIONS}

The results - apart from showing that membership in the EU has not led to an increase in the dynamics of both inward and outward FDI to V4 countries - bring our attention to the problem of positioning the V4 countries in the five stages of NOI.

Based upon the value of NOI in Tables 1-4, one may conclude that Hungary entered stage three of IDP in 2009. As for the Czech Republic, Poland and Slovakia, the situation is slightly ambiguous. Assuming that 2012 - as indicated earlier - was exceptionally tough for FDI, and that NOI for 2012 may be considered an exception, one may maintain that all of these three countries entered stage three of IDP in - respectively: 2010, 2010, and 2009.

If the above assumptions remain valid, one may conclude that the Czech Republic, Poland and Slovakia have made progress since - according to Gorynia, Nowak \& Wolniak (2010) and Boudier-Bensebaa (2008) - Hungary had been considered as reaching stage three of IDP earlier.

Consequently, these findings considerably extend those by Gorynia, Nowak \& Wolniak (2010) and Boudier-Bensebaa (2008).

There are, however, some limitations which have to be acknowledged. First and foremost, IDP should be considered in a broader context (Narula \& Guimón, 2010). For example, NOI should be confronted with the OPI index (Gorynia, Nowak \& Wolniak, 2010 , p. 16). It is highly probable that a slightly different picture could emerge. An estimation of the negative influence of the global financial crisis of 2007 on FDI to V4 countries could be equally important. Second, even sharing Stoian's (2013) positive opinion about the considerable explanatory power of Dunning's IDP, one may not only repeat after Durán \& Úbeda (2001) and Boudier-Bensebaa (2008) that it is necessary to redefine the fourth stage of IDP, but also to revise the criteria for classification into certain stages to avoid discrepancies in attributing particular countries to certain stages. Third, further conceptual work is needed with respect to the whole IDP model, especially concerning the various econometric models which should successfully address the idiosyncratic economic structure of these countries.

The V4 countries' membership in the European Union has not resulted in the speeding up of dynamic FDI in these countries (with respect to both inward and outward FDI). Despite this, V4 countries have already moved to stage three of IDP.

\section{REFERENCES}

Ambroziak, L. (2012). FDI and Intra-industry trade: theory and empirical evidence from the Visegrad countries. International Journal of Economics and Business Research, 4(1-2), 180-198.

Boudier-Bensebaa, F. (2008). FDI - assisted development in the light of the investment development path paradigm: evidence from Central and Eastern European countries. Transnational Corporations, 17(1), 37-67. 
Durán, J.J., \& Úbeda, F. (2001). The investment development path: a new empirical approach and some theoretical issues. Transnational Corporations, 10(2), 1-34.

Durán, J.J., \& Úbeda, F. (2005). The investment development path of newly developed countries. International Journal of the Economics of Business, 12(1), 123-137.

Fonseca, M., Mendonça, A., \& Passos, J. (2007). The Investment Development Path Hypothesis: Evidence from the Portuguese Case - A Panel Data Analysis, School of Economics and Management, Technical University of Lisbon, Working Papers 021/2007/DE. Retrieved on December 18, 2013, from https://www.repository.utl.pt/bitstream/10400.5/814/1/wp212007-\%20de.pdf

Gorynia, M., Nowak, J., \& Wolniak, R. (2007). Poland and its investment development path. Eastern European Economics, 45(2), 52-74.

Gorynia, M., Nowak, J., \& Wolniak, R. (2010). Foreign Direct Investment in Central and Eastern Europe: The IDP trajectories of selected countries. Poznań University of Economics Review, 10(1), 5-26.

Herrmann, S., \& Jochem, A. (2005). Trade balance of the Central and East European EU member states and the role of foreign direct investment. Deutsche Bundesbank, Research Centre, Discussion Paper Series 1: Economic Studies, no. 41. Retrieved on December 18, 2013, from Available from http://www.econstor.eu/bitstream/10419/19626/1/200541dkp.pdf

Kayam, S.S., \& Hisarciklilar, M. (2009). Revisiting the investment development path (IDP): a non linear fluctuation approach. International Journal of Applied Econometrics and Quantitative Studies, 6(2), 63-82.

Kornecki, L. (2008). Foreign direct investment and macroeconomic changes in CEE Integrating into the global market. Investment Management and Financial Innovations, 5(4), 124-132.

Kravtsova, V. (2014). Productivity change and externalities: empirical evidence from hungary. International Review of Applied Economics, 28(1), 102-125.

Kuti, M. (2005). The role of FDI in the external financing of the national economy. Development and Finance/Fejlesztes es Finanszirozas: Quarterly Hungarian Economic Review, 2, 54-65.

Mutascu, M., Hetes, R., \& Miru, O. (2010). The general framework for foreign direct investments attraction in Central and Eastern European Countries. Review of Economic and Business Studies, 3(2), 65-87.

Narula, R., \& Guimón, J. (2010). The investment development path in a globalised world: implications for Eastern Europe. Eastern Journal of European Studies, 1(2), 5-19.

Nowak, A.Z., \& Steagall, J.W. (2002). Foreign direct investment patterns and consequences in Central and Eastern Europe, 1990-2000. Transformations in Business and Economics, 1(1-2), 132-151.

Nucu, A.E. (2011). The Dynamics of Foreign Direct Investments in Central and Eastern Europe under the Impact of International Crisis of 2007. Centre for European Studies Working Papers, III, (1), 81-91. Retrieved on December 18, 2013, from http://www.cse.uaic.ro/ WorkingPapers/articles/CESWP2011_III1_NUC.pdf

Onaran, Ö. (2008). Jobless Growth in the Central and Eastern European Countries. Political Economy Research Institute, University of Massachusetts at Amherst, Working Paper Series, no. 165. Retrieved on December 18, 2013, from http://scholarworks.umass.edu/cgi/ viewcontent.cgi?article $=1136 \&$ context=peri_workingpapers

Onaran, Ö., \& Stockhammer, E. (2008). The effect of FDI and foreign trade on wages in the Central and Eastern European Countries in the post-transition era: a sectoral analysis for the manufacturing industry. Structural Change and Economic Dynamics, 19, 66-80. 
Pelinescu, E., \& Radulescu, M. (2009). Impact of foreign direct investment on the economic growth and countries' export potential. Romanian Journal of Economic Forecasting, 12(4), 153-169.

Rugraff, E. (2008). Are the FDI policies of the Central European countries efficient?. PostCommunist Economies, 20(3), 303-316.

Sass, M. (2004). FDI in Hungary - EIB Papers, 9(2), 62-90.

Stoian, C. (2013). Extending Dunning's Investment Development Path: The role of home country institutional determinants in explaining outward foreign direct investment. International Business Review, 22, 615-637.

UNCTAD (2013). World Investment Report 2013.Global Value Chains: Investment and Trade for Development.

Zámborský, P. (2012). Competitiveness gap and host country effects of FDI in the new OECD. International Journal of Trade and Global Markets, 5(3-4), 336-354.

\section{Author}

\section{Jacek Klich}

Associate Professor of Economics at Cracow University of Economics His research covers three main fields, namely small and medium-sized firm's growth and development, private sectors in transformed economies (with a special emphasis on national health care systems), as well as management and entrepreneurship in health care sectors.

\section{Correspondence to:}

Prof. UEK dr hab. Jacek Klich, PhD

Cracow University of Economics

Faculty of Economics and International Relations

Department of Public Economy and Administration

ul. Rakowicka 16, 31-510 Kraków, Poland

uuklich@cyf-kr.edu.pl 
